TAHKIM, Jurnal Peradaban dan Hukum Islam. Vol.3 No.l (Maret, 2020) | ISSN : 2597-7962

\title{
PRO DAN KONTRA SERTIFIKASI PERNIKAHAN
}

\author{
Intan Nurrachmi, Neng Dewi Himayasari \\ Fakultas Syariah Universitas Islam Bandung \\ intannurrachmi@gmail.com
}

\begin{abstract}
ABSTRAK
Program bimbingan pra nikah atau disebut kursus calon pengantin dapat diselenggarakan oleh Kementrian Agama, Kantor Urusan Agama atau Instansi dan Lembaga yang telah ditetapkan oleh Kementrian Agama. Bimbingan ini bertujuan untuk memberikan ilmu pengetahuan tentang syariah Islam dalam kehidupan rumah tangga guna bekal untuk mencapai keluarga yang sakinah mawaddah warahmah.Penelitian ini dilatarbelakangi oleh Keputusan Dirjen Bimbingan Masyarakat Islam Nomor. 373 Tahun 2017 tentang Petunjuk Teknis Bimbingan Perkawinan Bagi Calon Pengantin. Dalam aturan tersebut hanya berisikan materil/ teknis/ manajerial tanpa adanya substansi hukum yang mengikat sehingga fenomenanya kini terjadinya pro dan kontra dengan diberlakukannya kewajiban sertifikat pra nikah dalam persyaratan pendaftaran pernikahan.Penelitian ini bersifat qualitative research dengan kajian analisis normative deskriptif. Pendekatan yang digunakan dalam penelitian ini yaitu library research dan field research, dari penelitian ini yaitu sebagai jurnal agar bisa menjadi sumber rujukan tentang polemik pro dan kontra keberlakuan sertifikat pra nikah baik untuk penulisan skripsi, tesis, makalah, dan jurnal serta sebagai pengayaan bahan ajar mata kuliah di prodi Ahwal Syakhsiyyah bagi mahasiswa. Selain itu, hasil penelitian ini diharapkan dapat dijadikan rujukan dan tolok ukur untuk penegak hukum dan masyarakat dalam menilai kebijakan
\end{abstract}

\section{Kata Kunci : Perkawinan, Sertifikat Pra nikah, Syariat Islam}

\begin{abstract}
Pre-marriage counseling programs or so-called bride-to-be courses can be organized by the Ministry of Religion, the Office of Religious Affairs or Agencies and Institutions that have been established by the Ministry of Religion. This guidance aims to provide knowledge about Islamic sharia in domestic life in order to reach families who are confident in mawaddah warahmah. This research is motivated by the Decree of the Director General of Islamic Community Guidance Number. 373 of 2017 concerning Technical Guidance for Marriage Guidance for Prospective Brides. In these rules only contain material / technical / managerial without any binding legal substance so that the phenomenon is now the pros and cons of the imposition of pre-marital certificate obligations in the requirements of marriage registration. This research is qualitative research with descriptive normative analysis studies. The approach used in this research is library research and field research, from this research that is as a journal so that it can be a source of reference about the pros and cons polemics of the validity of premarital certificates both for writing thesis, theses, papers, and journals as well as enriching teaching materials study at Ahwal Syakhsiyyah study program for students. In
\end{abstract}


TAHKIM, Jurnal Peradaban dan Hukum Islam. Vol.3 No.l (Maret, 2020) | ISSN : 2597-7962

addition, the results of this study are expected to be used as a reference and benchmark for law enforcement and the community in assessing policy

\section{Keywords : Marriage, Prenuptial Certificate, Islamic Sharia}

\section{A. PENDAHULUAN}

Perkawinan adalah ikatan lahir batin antara seorang pria dan seorang wanita sebagai suami istri dengan tujuan membentuk keluarga (rumah tangga) yang bahagia dan kekal berdasarkan Ketuhanan Yang Maha Esa ${ }^{1}$ dan merupakan sunatullah yang umum dan berlaku pada semua mahluk-Nya, sebagai salah satu cara yang dipilih Allah SWT sebagai jalan bagi mahluk-Nya untuk berekembang biak dan melestarikan hidupnya ${ }^{2}$. Dalam Kompilasi Hukum Islam di Indonesia bahwa perkawinan menurut Hukum Islam adalah pernikahan, yaitu akad yang sangat kuat atau mitsaqon ghalidan untuk mentaati perintah Allah dan melaksanakannya merupakan ibadah. Perkawinan bertujuan untuk mewujudkan rumah tangga yang sakinah mawaddah warahmah. Untuk mewujudkan hal tersebut munculah wacana pemerintah melalui Kementrian Agama, Badan Kependudukan dan Keluarga Berencana (BKKBN) bersama beberapa kementerian yakni melalui Menteri Koordinator Bidang Pembangunan Manusia dan Kebudayaan (Menko PMK) yang akan menerbitkan sertifikasi pra-nikah agar terlaksananya perkawinana yang kuat. Namun hal ini banyak melahirkan pro-kontra di kalangan masyarakat yakni untuk menyertakan sertifikat pranikah sebagai syarat pernikahan akan segera terealisasi.

Sertifikat pranikah akan didapat oleh pasangan yang telah menjalani pelatihan berbagai pengetahuan seputar pernikahan, termasuk soal mengelola emosi, keuangan, hingga pengetahuan soal kesehatan dan alat reproduksi. Menurut Deputi Bidang Keluarga Sejahtera dan Pemberdayaan Keluarga BKKBN RI bahwa pihaknya berkoordinasi dengan Kementerian Agama, Kementerian Kesehatan, dan Kementerian Pemberdayaan Perempuan dan Perlindungan Anak (PPPA) terkait hal ini. Alasannya, ketiga kementerian tersebut mempunyai andil besar dalam mewujudkan

\footnotetext{
${ }^{1}$ Undang-Undang No 1 Tahun 1974 Tentang Perkawinan.

2 Siska Lis Sulistiani, dkk. Analisis Hukum Tentang Upaya Mediator Dalam Meminimalisir Jumlah Perceraian Di Pengadilan Agama Kelas 1A Kabupaten Indramayu ( Studi Kasus Perkara Perceraian Tahun 2016-2018). Tahkim Jurnal Peradaban dan Hukum Islam. Vol 2.No.2 (Oktober, 2019), hlm.68
} 
TAHKIM, Jurnal Peradaban dan Hukum Islam. Vol.3 No.l (Maret, 2020) | ISSN : 2597-7962

ketahanan keluarga, yakni keluarga yang tenteram, mandiri, dan bahagia, serta menjalankan delapan fungsi keluarga. ${ }^{3}$ yaitu; (1) hubungan suami istri seimbang, (2) nafsu seksual tersalurkan dengan baik, (3) anak terdidik menjadi anak yang saleh dan salehah, (4) terpenuhi kebutuhan lahir batin suami istri, (5) terjalin ikatan persaudaraan yang harmonis antara pihak keluarga besar suami dan istri, (6) mampu menjalankan perintah agama dengan baik, (7) mampu menjalin hubungan yang baik dengan tetangga sekitar, dan (8) mampu hidup dalam masyarakat dan Negara. ${ }^{4}$

Tujuan dari program ini selain untuk mewujudkan perkawinan yang kuat, juga untuk mengetahui kondisi kesehatan calon pengantin, membekali informasi kesehatan fisik dan psikis, serta memastikan calon pengantin siap berumah tangga. karena dapat mematangkan mental pasangan yang menikah, syaratnya bimbingan tersebut ${ }^{5}$. Oleh karena ini, pelatihan ini tidak hanya menjadi tanggungjawab Kementrian Agama, namun pelatihan ini nantinya agar bekerjasama dengan kementerian kesehatan, karena pasangan calon pengantin akan dibekali pengetahuan soal ekonomi keluarga hingga saran yang harus dilakukan ketika berumah tangga. ${ }^{6}$. Selanjutnya ide ini dibuat agar pasangan punya pengetahuan soal reproduksi sampai kondisi-kondisi berbahaya bagi anak seperti stunting. Selain mengenai kesehatan, pasangan akan dibekali pengetahuan soal ekonomi keluarga hingga saran yang bersifat spiritual. Tujuan lain dari adanya aturan ini adalah meminimalisir angka perceraian yang ada di Indonesia. Hal ini didukung pula oleh Komnas Perempuan adanya usulan tentang sertifikat perkawinan ini. Dengan syarat, pasangan nantinya akan mengimplementasikan ke dalam rumah tangga mereka, jadi tidak hanya sebatas formalitas.

Bimbingan pranikah sebenarnya telah ada sebelum polemik sertifikasi layak nikah diberlakukan pada 2020. Berdasarkan berbagai sumber yang telah dihimpun, bimbingan

3 Djumriah Lina Johan. Menakar Substansi Sertifikasi Nikah . Lihat: https://jurnalislam.com/menakar-substansi-sertifikasi-nikah/ diakses 25 januari 2020 pukul 20.00 wib

${ }^{4}$ Machfud, Membentuk Keluarga Ideal, (Surabaya: Jawara, 2002), hlm. 22.

${ }_{5}^{5}$ Audia Natasha Putri. Mulai 2020 Pasangan Yang Akan Menikah Wajib Miliki Sertifikat Layak Kawin Begini-Cara Dapatkannya . Lihat: https://palu.tribunnews.com/2019/11/21/mulai-2020-pasanganyang-akan-menikah-wajib-miliki-sertifikat-layak-kawin-begini-cara-dapatkannya?page=2 26 januari 2020 pukul $15.00 \mathrm{wib}$

6 https://sriwijayatv.com/2019/12/23/2020-pasangan-yang-akan-menikah-wajib-miliki-sertifikatpranikah/. Di akses 25 Januari 2020 
TAHKIM, Jurnal Peradaban dan Hukum Islam. Vol.3 No.l (Maret, 2020) | ISSN : 2597-7962

pra-nikah telah lama dilakukan oleh Kementerian Agama. Yakni dalam Keputusan Dirjen Bimas Islam no DJ.III/342 tahun 2016, Keputusan Bersama MA RI no. 574 tahun 1999 dan Keputusan Dirjen Bimbingan Masyarakat Islam Nomor. 373 Tahun 2017 tentang Petunjuk Teknis Bimbingan Perkawinan Bagi Calon Pengantin. Bimbingan pra nikah atau kursus calon pengantin merupakan bimbingan yang diberikan oleh pihak Kantor Urusan Agama kepada calon pengantin yang akan melangsungkan pernikahan. Bimbingan ini dilaksanakan untuk memberikan arahan pengetahuan serta sebagai bekal untuk menjalin rumah tangga sakinah mawaddah wa rahmah, sehingga kelak manjadi keluarga yang kokoh dan terhindar dari perceraian.

\section{B. METODE PENELITIAN}

\section{Sifat Penelitian}

Penelitian ini bersifat qualitative research dengan kajian analisis normatif deskriptif. Artinya data yang sudah terkumpul dianalisis kemudian dideskripsikan. Pendekatan yang digunakan dalam penelitian ini yaitu library research dan field research, artinya sumber data diambil dari kepustakaan yang ada dan dari lapangan. Instrument pengumpulan data yang digunakan yaitu pedoman wawancara. Dari hasil analisis tersebut dapat diketahui serta diperoleh kesimpulan induktif, yaitu cara berpikir dalam mengambil kesimpulan secara umum yang didasarkan atas fakta-fakta yang bersifat khusus ${ }^{7}$.

\section{Objek Penelitian}

Objek pada penelitian ini adalah Keputusan Dirjen Bimbingan Masyarakat Islam No. 373 Tahun 2017 tentang Petunjuk Teknis Bimbingan Perkawinan Bagi Calon Pengantin. Penulis akan mengkaji aturan diatas karena dirasa ada kekosongan hukum didalamnya, nyatanya hingga saat ini program bimbingan pra nikah dianggap tidak penting oleh masyarakat dan hanya mengatakan bahwa ini adalah formalitas saja dan permainan politik sehingga untuk memperkuat Keputusan dirjen BIMAS tersebut akan dibuat aturan diwajibkannya mengenai sertifikasi pranikah.

\footnotetext{
${ }^{7}$ Soerjono Soekanto, Pengantar Penelitian Hukum, (Jakarta : UI Press, 1986), hlm. 10
} 
TAHKIM, Jurnal Peradaban dan Hukum Islam. Vol.3 No.l (Maret, 2020) | ISSN : 2597-7962

\section{Variabel Data dan Definisi Operasional}

Variabel dan definisi operasional yang akan digunakan meliputi:

a. Bimbingan perkawinan pra nikah/ Kursus pra nikah adalah pemberian bekal pengetahuan, pemahaman, keterampilan dan penumbuh kesadaran kepada remaja usia nikah tentang kehidupan rumah tangga dan keluarga.

b. Sertifikat pra nikah adalah Surat bukti kompetensi lulus pelatihan pernikahan yang dikeluarkan oleh instansi yang berwenang.

c. Koordinator penyelenggara bimbingan calon pengantin adalah kepala seksi yang membidangi Urusan Agama Islam/ Bimbingan Masyarakat Islam pada Kantor Kementerian Agama Kabupaten/Kota, Pemberdayaan Keluarga BKKBN RI, Kementerian Kesehatan, dan Kementerian Pemberdayaan Perempuan dan Perlindungan Anak (PPPA).

\section{Jenis dan Sumber Data}

a. Library Research

Library Research merupakan penelitian kepustakaan, yang dilakukan dengan mencari data dari buku, jurnal, peraturan perundang-undangan, dan tulisan-tulisan ilmiah lainnya. Pada penelitian ini, peneliti akan meneliti baik dari hukum Islam, maupun dari Undang-undang perkawinan berupa peraturan perundang-undangan yang berlaku di Indonesia.

b. Field Research

Field Research merupakan penelitian lapangan yang pengumpulan datanya dilakukan dengan melakukan studi lapangan, baik dengan cara observasi, wawancara, Pada penelitian ini, peneliti akan mengumpulkan data dengan cara wawancara pada tokoh-tokoh yang relevan dengan penelitian, yaitu para pakar.

\section{PEMBAHASAN}

Pra nikah tersusun dari dua kata yaitu "pra” dan "nikah", kata "pra” sebagaimana yang tercantum di dalam "Kamus Besar Bahasa Indonesia" ialah sebuah awalan yang 
TAHKIM, Jurnal Peradaban dan Hukum Islam. Vol.3 No.l (Maret, 2020) | ISSN : 2597-7962

memiliki makna "sebelum". Sedangkan kata "nikah" diartikan di dalam "Kamus Besar Bahasa Indonesia" ialah sebagai sebuah ikatan atau perjanjian (akad) perkawinan antara seorang laki-laki dan seorang perempuan yang dilaksanakan sesuai dengan ketentuan hukum Negara dan agama. ${ }^{9}$

Salah satu pendidikan pra nikah dapat memberikan manfaat diantaranya ialah untuk mencapai sebuah keluarga yang damai, tentram, dan bahagia serta senantiasa diliputi rasa kasih sayang antar anggota keluarga sehingga mereka dapat bersosial dengan baik di dalam masyarakat. Keluarga yang bahagia tidak akan terwujud dengan mudah tanpa adanya pendidikan atau kebiasaan-kebiasaan baik yang dimulai dari dalam keluarga itu sendiri. Dengan demikian, dalam mewujudkan keluarga yang bahagia hendaknya anggota keluarga menyadari pentingnya sebuah proses pendidikan yang sesuai dengan syari'at sehingga proses transformasi perilaku dan sikap anggota keluarga akan tercermin dalam kepribadian yang baik yang sesuai dengan tuntunan yang disyari'atkan oleh agama. ${ }^{10}$

Pengertian dari keluarga adalah lingkup unit terkecil pada masyarakat yang merupakan sebuah lingkungan pendidikan pertama dan sangat berpengaruh besar bagi perkembangan anak. Baik dan buruknya sikap anak ditentukan oleh pola asuh dan pendidikan yang diterapkan oleh kedua orang tua kepada anak-anaknya di dalam rumah. Dengan demikian, hendaknya kedua orang tua saling berusaha menciptakan suasana rumah tangga yang harmonis, saling asah asih dan asuh yang dilandasi dengan ajaran dan nilai agama, sehingga mampu memberikan pendidikan terbaik sejak dini bagi anakanaknya. ${ }^{11}$ Oleh karena itu perlu diwujudkannya Keluarga yang ideal, yakni keluarga yang sakinah mawadah wa rahmah, untuk mencapai keluarga ideal tersebut ada prinsipprinsip yang harus di ketahui dan dipenuhi oleh calon mempelai. Prinsip-prinsip tersebut mencakup aspek internal dan aspek eksternal. Aspek internal mencakup: pemuliaan manusia, memilih pasangan sesuai hati nurani, bermitra, musyawarah, kecintaan, tidak adanya kekerasan, keadilan dan al ma"ruf. Sedang aspek eksternal adalah bertetangga

${ }^{8}$ Departemen Pendidikan dan Kebudayaan, Kamus Besar Bahasa Indonesia, (Jakarta : Balai Pustaka, 1998), hlm. 44-55.

9 Ibid.,hlm. 614.

${ }^{10}$ Amir Syarifuddin, Hukum Perkawinan Islam di Indonesia. (Jakarta : Kencana, 2007), hlm. 20

${ }^{11}$ Ditjen Bimas Islam, Pegangan Calon Penganten. (Jakarta: Depag RI, 2003), hlm. 241 
TAHKIM, Jurnal Peradaban dan Hukum Islam. Vol.3 No.l (Maret, 2020) | ISSN : 2597-7962

yang baik $^{12}$ bahwa keluarga sakinah adalah keluarga yang harmonis, bahagia dan sejahtera lahir batin, hidup tenang, tentram, damai, dan penuh kasih sayang. Dalam keluarga sakinah memiliki dimensi atau kriteria, yaitu; (1) hubungan suami istri seimbang, (2) nafsu seksual tersalurkan dengan baik, (3) anak terdidik menjadi anak yang saleh dan salehah, (4) terpenuhi kebutuhan lahir batin suami istri, (5) terjalin ikatan persaudaraan yang harmonis antara pihak keluarga besar suami dan istri, (6) mampu menjalankan perintah agama dengan baik, (7) mampu menjalin hubungan yang baik dengan tetangga sekitar, dan (8) mampu hidup dalam masyarakat dan Negara. ${ }^{13}$

Islam telah mengatur suatu konsep dalam kehidupan keluarga, sebagaimana yang telah Allah Subhanahu Wa Ta"ala firmankan dalam al-Qur'an Surah ar-Ruum ayat 21 sebagai berikut:

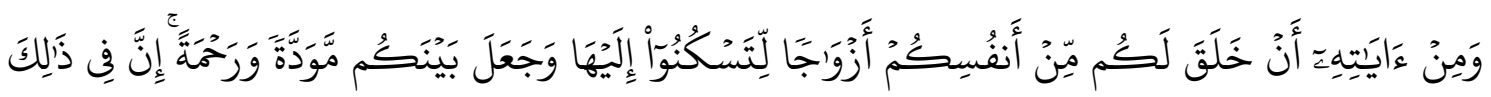

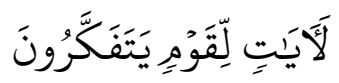

"Dan di antara tanda-tanda kekuasaan-Nya ialah Dia menciptakan untukmu isteri-isteri dari jenismu sendiri, supaya kamu cenderung dan merasa tenteram kepadanya, dan dijadikan-Nya diantaramu rasa kasih dan sayang. Sesungguhnya pada yang demikian itu benar-benar terdapat tanda-tanda bagi kaum yang berfikir. "(Qs. arRuum: 21$).{ }^{14}$

Oleh karena itu untuk mempersiapkan konsep kehidupan keluaraga, diperlukan adanya kesiapan menikah terdiri dari kemampuan pasangan dalam komunikasi, pengaturan keuangan, kesepakatan tentang pengasuhan anak, pembagian peran suami istri, kemampuan menerima latar belakang pasangan (suku, agama), kemampuan menjaga relasi dengan keluarga besar, kemmampuan membagi waktu untuk berdua dan melaksanakan minat pribadi, kemampuan menghadapi perubahan pola hidup setelah

${ }^{12}$ Yusdani, Menuju Fiqih Keluarga Progresif . (Yogyakarta: Kaukaba Dipantara, 2011), hlm. 183.

13 Machfud, Membentuk Keluarga Ideal, (Surabaya: Jawara, 2002), hlm. 22.

14 Departemen Agama RI, Al-Quran dan Terjemahnya, (Bandung: CV Penerbit Diponegoro, 2006, Cet. Ke-10, hlm. 324. 
TAHKIM, Jurnal Peradaban dan Hukum Islam. Vol.3 No.l (Maret, 2020) | ISSN : 2597-7962

menikah. ${ }^{15}$ Berikut adalah beberapa kesiapan yang harus dimiliki oleh kedua calon pengantin diantaranya yaitu; kesiapan fisik, kesiapan mental, dan kesiapan ekonomi. Ketiga hal ini umumnya menjadi pemicu sebuah ketakutan bagi orang-orang yang hendak memasuki jenjang pernikahan.

\section{Kesiapan Fisik}

Kesiapan yang dimaksud dalam hal ini adalah keadaan siap yang tercermin pada diri seseorang. Siap secara fisik artinya seseorang sudah matang perkembangan anggota tubuhnya. Seorang laki-laki dan perempuan yang memutuskan menikah hendaknya memeriksakan diri terkait dengan kesehatan fisik dan kesehatan reproduksinya. Hal ini penting dilakukan untuk mendeteksi kesehatan reproduksi pasangan sejak dini, sehingga setelah menikah diharapkan kedua pasangan ini mampu melaksanakan fungsinya sebagai suami istri secara optimal dan mampu melahirkan keturunan yang sehat. Apabila ada gangguan terhadap organ reproduksinya misalkan ditemukan adanya penyakit dan kelainan tertentu, maka harus segera diobati ${ }^{16}$ Fisik yang indah akan menjadikan salah satu faktor pendorong manusia untuk merasa bangga, senang dan bahagia. Maka dari itu, hendaknya setiap orang memperhatian kebersihan, kerapian, dan kesehatan fisiknya, karena fisik yang sehat akan menunjang kesiapan beraktifitas dan bekerja.

\section{Kesiapan Mental}

Kesiapan mental merupakan sebuah permasalahan yang seringkali muncul pada diri seseorang dalam segala hal termasuk pada saat hendak melangsungkan pernikahan. Tidak sedikit orang yang dibayangi keragu-raguan, sehingga menimbulkan kebimbangan. Menikah harus diniatkan dengan benar yaitu karena memenuhi kebutuhan hidup sebagai makhluk sosial serta sebagai bentuk ketaatan (ibadah) kepadaAllah. Seseorang yang memiliki kesadaran niat yang lurus bahwa menikah adalah sebagai bentuk ibadah kepada Allah maka berarti secara mental ia telah siap untuk menikah

\section{Kesiapan Ekonomi}

Kesiapan ekonomi yakni keadaan seseorang yang siap secara materi untuk melangsungkan pernikahan. Siap secara ekonomi tidak berarti harus kaya raya, akan

15 https://psychology.binus.ac.id, kesiapan-menikah-vs-persiapan-pernikahan/, Tahun 2015, diakses tgl 30 Januari 2020.

${ }^{16}$ Tim perwakilan BKKBN, Modul; Orientasi Diseminasi Program KKBPK Bagi Petugas Pernikahan dalam Memberikan Nasihat Kepada Calon Pengantin, (Surabaya: BKKBN, 2017), hlm. 52. 
TAHKIM, Jurnal Peradaban dan Hukum Islam. Vol.3 No.l (Maret, 2020) | ISSN : 2597-7962

tetapi adanya kesiapan untuk memberikan nafkah kelak bagi anggota keluarga. Islam tidak menghendaki pemeluknya berpikiran dan hidup secara materialistis (money oriented), akan tetapi penting bagi calon suami maupun istri untuk memiliki kemampuan bekerja keras sehingga mampu membiayai hidup serta mampu mengelola keuangan agar kesejahteraan ekonomi keluarga dapat terjamin. ${ }^{17}$

Jika melihat pandangan Kementerian Agama dan Badan Kependudukan dan Keluarga Berencana Nasional (BKKBN), kedua instansi ini terlihat menyambut positif akan rencana aturan baru tersebut. Bahkan, Kementrian Agama akan menyiapkan Kantor Urusan Agama (KUA) di seluruh daerah di Indonesia untuk melakukan pendidikan pranikah bagi calon pasangan. Sepintas memang tidak ada yang salah dengan aturan tersebut. Bahkan, pengetahuan tentang berumah tangga merupakan suatu hal wajib yang harus diketahui oleh masing-masing calon pasangan. Karena tidak bisa dipungkiri untuk menuju ke jenjang pernikahan diperlukan tidak hanya bermodalkan materi semata, tetapi juga kesiapan fisik dan juga mental.

Oleh karena itu pengetahuan tentang berumah tangga, pentingnya menghadapi permasalahan ekonomi, hingga kesehatan reproduksi adalah hal-hal yang wajib diketahui oleh setiap pasangan. Kita perlu memahami teori dahulu sebelum melakukan praktik. Pengetahuan atau edukasi ini merupakan salah satu keuntungan dari kebijakan pra-nikah. Materi yang disampaikan dalam kursus antara lain fiqih mukahat, kewajiban dan hak suami istri, undang-undang perkawinan, psikologi keluarga, komunikasi efektif, kesehatan keluarga, dan keluarga berencana. Dalam waktu 2 x 8jam, Pemateri diharapkan mampu menerangkan seluruh materi yang disampaikan secara detail dan menyeluruh. ${ }^{18}$

Lahirnya Peraturan Direktur Jendral Bimbingan Masyarakat Islam Departemen Agama tentang Kursus Calon Pengantin atau Kursus Pra Nikah sebagai bekal membangun keluarga sakinah sekaligus antisipan dari berbagai persoalan keluarga

\footnotetext{
${ }^{17}$ Ibid, hlm. 17

${ }^{18}$ Halimah Dian Nastity, Heru Siswanto. Penyelenggaraan “Kursus Pra Nikah” Dalam Perspektif Pendidikan Luar Sekolah Di Badan Penasihatan Pembinaan Dan Pelestarian Perkawinan (Bp4) Kecamatan Wonocolo Kota Surabaya. Jurnal Pendidikan Untuk Semua. https://journal.unesa.ac.id/index.php/jpls/index. (Surabaya : Universitas Negeri Surabaya, 2019), hlm. 5
} 
TAHKIM, Jurnal Peradaban dan Hukum Islam. Vol.3 No.l (Maret, 2020) | ISSN : 2597-7962

menjadi tumpuan harapan bagi calon pasangan pengantin. ${ }^{19}$ Berdasarkan rujukan data dari hukumonline.com tahun 2016, tercatat sebanyak 403.070 perkara perceraian dengan putusan sebanyak 365.654 perkara. Sedangkan tahun 2017, tercatat totalnya sebanyak 415.848 perkara dan yang diputus sebanyak 374.516 perkara. Sehingga, tren perkara perceraian yang diputus dalam tiga tahun terakhir itu ada pada kisaran 353.843 hingga 374.516 perkara. ${ }^{20}$ Dari data faktor penyebab perceraian tahun 2017 di Pengadilan Agama seluruh Indonesia, terlihat lebih didominasi oleh adanya alasan/faktor perselisihan dan pertengkaran terus menerus yang menempati urutan pertama atau terbanyak. Selanjutnya terbanyak kedua yang menjadi penyebab perceraian adalah faktor persoalan ekonomi. Sedangkan urutan ketiga terbanyak penyebab perceraian yakni meninggalkan salah satu pihak. Melihat hal tersebut jadi maksud pemerintah hendak menjalankan program sertifikasi layak nikah merupakan sesuatu yang perlu diapresiasi, walaupun belum ada kajian penelitian yang membuktikan bahwa pendidikan pranikah terbukti dapat mengurangi angka perceraian ataupun kekerasan dalam rumah tangga.

Selain permasalahan di atas, permasalahan stunting kondisi kurangnya gizi atau asupan makanan pada anak adalah hal yang perlu mendapatkan perhatian khusus. Selama ini permasalahan kemiskinan dalam berumah tangga berawal dari ketidaksiapan finansial. Hal itu kerap kali berujung pada abainya pasangan suami-istri dalam memenuhi dan menyediakan kualitas gizi bagi keluarganya. Kondisi tersebut akan berbahaya apabila istri dalam keadaan hamil dan kekurangan asupan gizi. Hal tersebut dapat mengakibatkan janin yang di dalam kandungan bisa berpotensi mengalami stunting atau gizi buruk. Perlu diketahui juga bahwa status stunting di Indonesia masih tinggi. Merujuk pada data dari Kementrian Kesehatan Republik Indonesia, Pemantauan Status Gizi (PSG) 2017 menunjukkan prevalensi balita stunting di Indonesia masih tinggi, yakni 29,6\% di atas batasan yang ditetapkan WHO (20\%). ${ }^{21}$ Penelitian lain bahkan menemukan bahwa balita stunting berkontribusi terhadap 1,5 juta (15\%) kematian anak balita di dunia dan

\footnotetext{
${ }^{19}$ Lutfi Kusuma Dewi. Penerapan Nilai-Nilai Pendidikan Islam Dalam Pelaksanaan Kursus Pra Nikah Untuk Mewujudkan Keluarga Sakinah. Ta'dibuna: Jurnal Pendidikan Agama IslamVol. 2, No. 1, 2019. hlm. 36

20 Rofiq Hidayat. Melihat Tren Perceraian dan Dominasi Penyebabnya. 2018. Lihat: https://www.hukumonline.com. Diakses Tanggal 19 Februari 2020 Jam. 09.59

${ }^{21}$ Kemenkes RI, Buku Saku Pemantauan Status Gizi Tahun 2017. (Jakarta : Direktoran Gizi Masyarakat, 2018), hlm. 36.
} 
TAHKIM, Jurnal Peradaban dan Hukum Islam. Vol.3 No.l (Maret, 2020) | ISSN : 2597-7962

menyebabkan 55 juta anak kehilangan masa hidup sehat setiap tahun. Hal ini sejalan dengan pendapat Ketua Pimpinan Daerah Muhammadiah (PDM) Rembang, Ansori Solih sebagaimana yang dikutip www.liputan6.com yang menyatakan pelatihan pra-nikah tersebut juga bisa mencegah terjadinya stunting atau kelahiran bayi cebol (kerdil), sebab pencegahan harus dimulai dari sejak hamil. Pasalnya, kata dia, kasus stunting di Indonesia tahun 2018 mencapai 33 persen. ${ }^{22}$ Dalam hal ini Ansori secara ide ia setuju dengan adanya pelatihan pra nikah. Ia memberikan gambaran, pasangan yang berencana nikah akan mendapatkan informasi terkait hal-hal seputar pernikahan, tentang bagaimana saat mempunyai anak sehingga secara mental pasangan akan lebih siap untuk menikah. ${ }^{23}$

Namun disisi lain kalangan yang kontra terhadap peraturan adanya sertifikasi pra nikah yakni dengan alasan bahwa adanya sertifikat siap kawin sebelum menikah pada hakikatnya tidak termasuk rukun nikah maupun syarat sah menikah di dalam Islam. Dengan demikian, menjadikan sertifikat nikah sebagai salah satu syarat pernikahan tentulah tidak sesuai dengan syariat Islam.

Hal ini sebagaimana diungkapkan oleh Sekretaris PCNU Rembang, Muhtar Nur Halim sebagaimana dikutip liputan6.com yang berpendapat, apabila nantinya sertifikasi nikah digunakan sebagai syarat sah administrasi pernikahan, dirinya tidak setuju dan itu berbahaya. Sertifikasi nikah, kata dia, tidak termasuk syarat sah nikah dalam Islam. Jika tujuan pelatihan pra-nikah yang rencananya selama tiga bulan bertujuan untuk memberi pemahaman tentang pernikahan terhadap calon pengantin, menurutnya itu sudah ada dan dilakukan oleh lembaga pendidikan. Muhtar menyebutkan, di madrasah atau sekolah sudah ada pelajaran tentang bab nikah. Upaya tersebut, kata dia, bisa lebih efektif dengan menambah materi dalam kurikulum pendidikan tentang nikah. "Ya untuk menyelesaikan salah satu keanehan pemerintah tentang hal ini, tambah saja kurikulum tentang bab nikah di lembaga-lembaga pendidikan," ungkap Muhtar. Muhtar menyampaikan, adanya sertifikasi nikah nantinya malah membuat ribet calon pengantin yang akan menikah. Selain itu, kata dia, wacana ini mengingatkan adanya sertifikasi dalam banyak hal di

\footnotetext{
${ }^{22}$ Ahmad Adirin. Beda Pandangan Muhammadiyah dan NU Rembang soal Sertifikasi Nikah. 2019. Lihat: https://www.liputan6.com. Diakses Tanggal 19 Februari 2020

${ }^{23}$ Ibid.
} 
TAHKIM, Jurnal Peradaban dan Hukum Islam. Vol.3 No.l (Maret, 2020) | ISSN : 2597-7962

Indonesia seperti sertifikat halal yang diperebutkan antara MUI dengan Kementerian Agama yang ujung-ujungnya adalah proyek dan hal tersebut yang tak diharapkan. ${ }^{24}$

Selanjutnya mengenai banyaknya kasus stunting, rendahnya tingkat ekonomi rumah tangga, hingga tingginya angka perceraian bukan hanya karena kurangnya ilmu sebelum menikah tetapi lebih disebabkan karena sistem kapitalis sekuler yang menjadi akar permasalahan problematika kehidupan berumah tangga, masyarakat, maupun bernegara.

Berikut beberapa alasannya diantaranya rendahnya ekonomi di tingkat rumah tangga disebabkan karena sulitnya mencari pekerjaan di negara ini. Ketika suami memiliki pekerjaan pun tidak bisa memenuhi kebutuhan pokok berupa sandang, pangan, dan papan. Karena semakin hari harga kebutuhan pokok semakin tinggi apalagi ditambah naiknya iuran BPJS menambah beban bagi keluarga menengah ke bawah. Selanjutnya tingginya kasus stunting karena absennya Pemerintah dalam menjamin pemenuhan kebutuhan pokok yang halal, sehat, bergizi, seimbang, serta thayyib (baik). Kalaupun ada kebutuhan pokok yang halal dan thayyib harganya jauh lebih mahal. Sesuai dengan sebuah slogan yang berbunyi, "Harga sesuai dengan kualitas."Sehingga jika rakyat menengah ke bawah hanya memiliki uang sedikit maka hanya bisa membeli beras yang harganya murah dengan kualitas murahan. Maka beras tersebut sudah berbau dan sudah berubah warna. Oleh karena itul, wajar jika masih banyak kasus stunting di negeri ini.

Selain itu juga fator alasan yang penting yakni diakibatkan pergaulan yang serba bebas dan boleh mengakibatkan banyaknya generasi yang terjerumus kepada pergaulan bebas. Ditambah dengan adanya konten-konten yang berbau pornografi dan pornoaksi hingga masih beredarnya narkoba dan minuman keras di kalangan generasi sehingga kasusu yang terjadi adalah salahsatunya kehamilan tidak direncanakan pun terjadi. Inilah yang kebanyakan menjadi sebab mengapa banyak terjadi pernikahan dini. Dengan demikian, bukan solusi penyuluhan kesehatan reproduksi yang dibutuhkan. Begitu pula dengan rusaknya tatanan kehidupan keluarga karena perselingkuhan melalui media sosial menjadi salah satu pemicu. Tak sedikit pula yang bercerai karena istri yang turut

${ }^{24}$ Ibid. 
TAHKIM, Jurnal Peradaban dan Hukum Islam. Vol.3 No.l (Maret, 2020) | ISSN : 2597-7962

membantu keuangan keluarga akhirnya selingkuh dengan rekan sejawatnya. Hal ini pun berlaku sebaliknya.

Dengan demikian, sertifikat nikah yang dimaksudkan bukan menjadi solusi, karena Islam sebagai agama yang komprehensif memiliki solusi tuntas untuk permasalahan negeri ini. Karena Islam mengatur sistem pergaulan pria dan wanita dengan sudut pandang yang khas. Pria dan wanita tidak boleh berdua-dua (khalwat) maupun bercampur baur (ikhtilat). Dengan pemahaman yang khas ini disertai penanaman keimanan kepada Allah, akan menjadi rem bagi kaum Muslimin agar tidak terjerumus pergaulan bebas maupun perselingkuhan. Selain itu, anak-anak sedari kecil dididik dengan pendidikan sesuai fitrahnya sebagai laki-laki dan perempuan. Laki-laki dididik menjadi seorang pemimpin yang siap untuk memimpin keluarga dan siap untuk bertanggung jawab mencari nafkah sejak usia baligh. Sedangkan perempuan dididik agar siap menjadi istri dan pengatur rumah tangga. Sehingga ketika baligh, telah memahami dengan tupoksi masing-masing dan siap untuk menikah. Negara tidak serta merta melepaskan tangan melainkan negara wajib memberikan pendidikan tersebut sebagai bagian dari kurikulum. Negara pun mempermudah perizinan menikah bagi laki-laki dan perempuan yang sudah siap untuk menikah. Serta negara memfasilitasi dengan memberikan lapangan pekerjaan, pendidikan gratis, kesehatan gratis, keamanan gratis, hingga menjamin akan terpenuhinya kebutuhan pokok berupa sandang, pangan, dan papan.

Begitu pula aturan tersebut dirasa berlebihan oleh beberapa kalangan karena dianggap justru menghalangi pernikahan, yang akan mengakibatkan konsekuensi yang kontraproduktif atau merugikan. Terutama jika penerapan sertifikat pra-nikah dilakukan melalui pembelajaran yang cukup memakan waktu, apalagi jika mengakibatkan tidak dapat menikahnya pasangan calon pengantin karena tidak mendapatkan sertifikat tersebut. Beberapa konsekuensi yang kontraproduktif itu misalnya, adanya risiko perzinahan terkait dengan rumitnya persyaratan untuk mendapatkan buku nikah. Setelah itu, apabila telah lulus dan mendapatkan sertifikat pra nikah, apakah dapat menjamin bahwa pasangan tersebut tidak akan bercerai. Selanjutnya bagaimana pengaturan tentang seseorang yang akan menikah lagi dengan seseorang yang baru menikah, apakah harus 
TAHKIM, Jurnal Peradaban dan Hukum Islam. Vol.3 No.l (Maret, 2020) | ISSN : 2597-7962

mengikuti sertifikasi atau tidak. Sangat banyak aturan teknis yang harus dipersiapkan apabila akan menerapkan aturan ini.

\section{SIMPULAN}

Terjadinya pro dan kontra dalam program sertifikat pra nikah wajar terjadi karena pandangan masing masing ahli berbeda dengan tidak adanya ukuran yang mengarahkan bahwa program ini telah jelas dilegalkan oleh Negara. Polemik terjadi karena dampak fenomena yang tidak sinkron dengan program yang dibuat. Fenomena pro dan kontra ini terjadi karena tidak adanya penjelasan atas ketegasan dan maslahat yang dibuat oleh Negara untuk rakyatnya. Dalam aturan yang membahas bimbingan pra nikah hanya bersifat teknisi, sehingga orang orang hanya terikat dengan manajerial pelaksanaannya bukan dengan substansi hukumnya yang mengatakan bahwa pelaksanaan bimbingan pra nikah ini wajib atau tidak, sehingga ada kelonggaran hukum yang mengakibatkan persepsi individu yang mengabaikan program ini.

Untuk peninjauan kembali aturan Keputusan Dirjen Bimbingan Masyarakat Islam No. 373 Tahun 2017 tentang Petunjuk Teknis Bimbingan Perkawinan Bagi Calon Pengantin, maka penulis menuangankan keuntungan dari pihak menyatakan pro dan kerugian dari pihak menyatakan kontra dengan diberlakukannya sertifikat pra nikah sebagai salah satu syarat pendaftaran pernikahan. 
TAHKIM, Jurnal Peradaban dan Hukum Islam. Vol.3 No.l (Maret, 2020) | ISSN : 2597-7962

\section{DAFTAR PUSTAKA}

Departemen Agama RI. (2006). Al-Quran dan Terjemahnya, Cet. Ke-10, Bandung: CV Penerbit Diponegoro.

Departemen Pendidikan dan Kebudayaan. (1998). Kamus Besar Bahasa Indonesia. Jakarta : Balai Pustaka

Dewi, L. K. (2019). Penerapan Nilai-Nilai Pendidikan Islam Dalam Pelaksanaan Kursus Pra Nikah Untuk Mewujudkan Keluarga Sakinah. Ta'dibuna: Jurnal Pendidikan Agama IslamVol. 2, No. 1. Yogyakarta : Universitas Islam Negeri Sunan Kalijaga.

Ditjen Bimas Islam. (2003). Pegangan Calon Penganten. Jakarta: Depag Republik Indonesia

Kemenkes RI. (2018). Buku Saku Pemantauan Status Gizi Tahun 2017. Jakarta : Direktoran Gizi Masyarakat.

Machfud. (2002). Membentuk Keluarga Ideal. Surabaya : Jawara

Sulistiani, L.S (2019). dkk Analisis Hukum Tentang Upaya Mediator Dalam Meminimalisir Jumlah Perceraian Di Pengadilan Agama Kelas 1A Kabupaten Indramayu ( Studi Kasus Perkara Perceraian Tahun 2016-2018).Tahkim Jurnal Peradaban dan Hukum Islam. Vol 2.No.2 Oktober.

Syarifuddin, A. (2007). Hukum Perkawinan Islam di Indonesia. Jakarta : Kencana

Soekanto, S. (1986). Pengantar Penelitian Hukum. Jakarta : UI Press

Tim perwakilan BKKBN. (2017). Modul; Orientasi Diseminasi Program KKBPK Bagi Petugas Pernikahan dalam Memberikan Nasihat Kepada Calon Pengantin. Surabaya : BKKBN

Undang Undang No 1 Tahun 1974 Tentang Perkawinan

Putri, A. N. (2019) . Mulai 2020 pasangan yang akan menikah wajib miliki sertifikat layak kawin begini cara dapatkannya. https://palu.tribunnews.com. Diakeses Tanggal 26 Januari 2020

Yusdani. (2011) . Menuju Fiqih Keluarga Progresif. Yogyakarta: Kaukaba Dipantara.

\section{Website:}

Adirin, A. (2019). Beda Pandangan Muhammadiyah dan NU Rembang soal Sertifikasi Nikah. https://www.liputan6.com.. Diakses Tanggal 19 Februari 2020 
TAHKIM, Jurnal Peradaban dan Hukum Islam. Vol.3 No.l (Maret, 2020) | ISSN : 2597-7962

Johan, D. L. (2019). https://jurnalislam.com. Menakar substansi sertifikasi nikah/. Diakses Tanggal 28 Januari 2020

Hidayat, R. (2018). Melihat Tren Perceraian dan Dominasi Penyebabnya. https://www.hukumonline.com.. Diakses Tanggal 19 Februari 2020

https://psychology.binus.ac.id. (2015). Kesiapan menikah vs persiapan pernikahan/. Diakses Tanggal 30 Januari 2020

https://sriwijayatv.com. (2019). 2020 pasangan yang akan menikah wajib miliki sertifikat pranikah/. Diakses Tanggal 25 Januari 2020 